JURNAL KETAHANAN NASIONAL

Vol. 26, No. 1, April 2020, Hal 40-54

DOI:http://dx.doi.org/ 10.22146/jkn.53132

ISSN:0853-9340(Print), ISSN:2527-9688(Online)

Online sejak 28 Desember 2015 di :http://jurnal.ugm.ac.id/JKN

VOLUME 26

No. 1, April 2020

Halaman 40-54

\title{
Strategi Pembentukan Ketahanan Pribadi Siswa Berbasis Nilai-Nilai Pancasila Untuk Membangun Kesadaran Bernegara (Studi Di SMA Taruna Nusantara Magelang Jawa Tengah)
}

\author{
Diyah Kartika Dewi \\ Universitas Negeri Yogyakarta \\ email: diyahkdewi79@gmail.com \\ Sunarso \\ Universitas Negeri Yogyakarta \\ email: sunarso@uny.ac.id
}

\begin{abstract}
This study aims to analyze the strategy of forming student's personal resilience based on Pancasila values to build state awareness in Taruna Nusantara High School. This research uses a qualitative approach to the type of case study. Determination of the subject using a purposive technique. Data collection using observation and interview. The data analysis component uses interactive models while the validity of the data uses member check. The results showed that there were several strategies in the formation of personal endurance based on Pancasila values to build state awareness in Taruna Nusantara High School, namely (1) acculturation of Pancasila values through school culture using the exemplary and participatory approach of all school members, (2) carrying out project activities and, (3) the teacher carries out innovative learning. The formation of self-defense based on Pancasila values is important because it can produce a strong personality, nationalistic spirit, and be able to restore national identity.
\end{abstract}

Keywords: School Roles, Student's Personal Resilience, Acculturation of Pancasila Values, Having State Consciousness.

\begin{abstract}
ABSTRAK
Penelitian ini bertujuan untuk menganalisis strategi pembentukan ketahanan pribadi berbasis nilai-nilai Pancasila untuk membangun kesadaran bernegara di SMA Taruna Nusantara. Penelitian ini menggunakan pendekatan kualitatif dengan jenis studi kasus. Penentuan subjek menggunakan teknik purposive. Pengumpulan data dengan menggunakan observasi dan wawancara. Komponen analisis data menggunakan interactive models sedangkan keabsahan data menggunakan member check. Hasil penelitian menunjukkan bahwa terdapat beberapa strategi dalam pembentukan ketahanan pribadi berbasis nilai-nilai Pancasila untuk membangun kesadaran bernegara di SMA Taruna Nusantara, yaitu (1) pembudayaan nilai-nilai Pancasila melalui budaya sekolah dengan menggunakan pendekatan keteladanan dan partisipastif dari semua warga sekolah, (2) melaksanakan kegiatan terproyek dan, (3) guru melaksanakan pembelajaran yang inovatif. Pembentukan ketahanan diri siswa berbasis nilai-nilai Pancasila penting untuk dilakukan karena dapat menghasilkan pribadi yang tangguh, berjiwa nasionalis, dan mampu mengembalikan jati diri bangsa.
\end{abstract}

Kata Kunci: Peran Sekolah, Ketahanan Pribadi Siswa, Pembudayaan Nilai-nilai Pancasila, Kesadaran Bernegara. 
Diyah Kartika Dewi, Sunarso -- Strategi Pembentukan Ketahanan Pribadi Siswa Berbasis Nilai-Nilai Pancasila Untuk Membangun Kesadaran Bernegara (Studi Di SMA Taruna Nusantara Magelang Jawa Tengah)

\section{PENGANTAR}

Pancasila merupakan norma dasar dan pandangan hidup yang bersifat fundamental bagi bangsa Indonesia. Pancasila lahir berkat konsensus dari masyarakat yang menyatakan diri menjadi bagian dari bangsa ini. Akan tetapi, seiring dengan perkembangan yang ada berbagai trend digulirkan oleh lintas generasi yang menyebabkan berbagai perilaku, ucapan dan bahasa tubuh dianggap sesuatu yang umum atau biasa sehingga banyak hal diremehkan. Kondisi ini diperparah dengan berbagai penyajian informasi dan tontonan konflik dalam berita utama televisi dan menjadi bahan perbincangan media sosial yang menonjolkan kekuatan tiap-tiap kelompok, merendahkan martabat orang, dan menjadikan orang lain sebagai musuh karena berbeda pandangan (Pratomo, 2013).

Menurut Hafsah (2013) peristiwa tersebut dapat dianggap sebagai krisis jati diri bangsa yang ditandai dengan merosotnya nilainilai sebagai identitas nasional, menurunnya kualitas penghargaan dan pelaksanaan prinsip spiritualitas, humanitas, nasionalitas, soverenitas dan soliditas sebagai bangsa. Kritis jati diri bangsa tidak hanya ditunjukkan oleh masyarakat dewasa, akan tetapi sudah tampak pada generasi muda saat ini. Ryacudu (2019) menambahkan bahwa munculnya ancaman terhadap mindset dan bentuk perang modern yang sangat mempengaruhi masyarakat sehingga membelokkan pemahaman terhadap ideologi negara. Pembelokkan ideologi negara dapat mengakibatkan terjadinya konflik horizontal. Menurut Susatyo (2019) konflik horizontal karena identitas lokal muncul lebih kuat dibanding identitas nasional.

Berdasarkan permasalahan di atas, maka diperlukan suatu strategi untuk membangun kesadaran bernegara pada generasi muda sebagai penerus bangsa (Kompas.com, 13/9/2019). Kesadaran bernegara merupakan suatu kemauan yang timbul dari kesadaran pribadi untuk hidup terikat di bawah naungan bendera Merah Putih. Membangun kesadaran bernegara dapat diawali dari proses pembentukan ketahanan pribadi para siswa di sekolah. Ketahanan itu sendiri dapat diartikan sebagai ketangguhan untuk menghadapi segala ancaman diri. Untuk mencapai ketahanan nasional akan dimulai dari ketahanan pribadi yang meluas menjadi ketahanan bermasyarakat (Widayanti, Armawi, and Andayani, 2018: 7). Peningkatan kualitas pribadi merupakan suatu proses pembentukan ketahanan diri. Ketahanan diri pribadi dapat dilatih sejak dini dimulai dari hal-hal yang kecil seperti ulet, disiplin, percaya diri, dan bertanggung jawab untuk peningkatan kecakapan hidup melalui proses kegiatan sehari-hari baik di dalam keluarga, sekolah maupun masyarakat. Kecakapan hidup dapat diartikan sebagai suatu kompetensi yang dimiliki individu untuk menyesuaikan diri dengan lingkungan. Proses peningkatan kecakapan hidup individu tidaklah mudah, perlu upaya negara meningkatkan kualitas pendidikan melalui jalur formal. Pendidikan formal adalah pendidikan yang dibentuk secara sistematis dan berjenjang. Pendidikan formal menghendaki generasi muda ambil bagian dalam hal ini karena masa depan negara menjadi tanggung jawabnya. Menurut Martoredjo (2016: 120) lingkungan pendidikan formal mempunyai andil besar dalam membentuk ketahanan pribadi generasi muda, karena pemerintah mengambil kebijakan yang mewajibkan generasi ini menempuh pendidikan dasar 12 tahun. Dengan demikian, sekolah sebagai lembaga pendidikan formal dapat menjadi wadah penanaman dan pengembangan karakter 
yang baik atau sebagai tempat memperkuat pembentukan ketahanan pribadi siswa berbasis nilai-nilai Pancasila.

Dari uraian di atas, sangat jelas bahwa perlu peran sekolah dalam upaya pembentukan ketahanan pribadi siswa berbasis nilai-nilai Pancasila untuk membangun kesadaran bernegara. Sekolah harus memiliki program kegiatan yang didesain lewat kurikulum dalam membentuk karakter yang menjaga dan mempertahankan jati diri bangsa. Oleh karena itu, peneliti memiliki ketertarikan untuk dapat menganalisis peran sekolah sebagai upaya pembentukan ketahanan pribadi dalam membentuk dan mengelola mindset para siswa. Peneliti menunjuk SMA Taruna Nusantara Magelang sebagai lokasi penelitian dengan pertimbangan bahwa SMA Taruna Nusantara merupakan salah satu sekolah yang memiliki ciri kekhususan yaitu sekolah berasrama, rekruitmen peserta didik dari seluruh nusantara, dan menerapkan kurikulum nasional 2013 serta kurikulum khusus dengan pendekatan wawasan kebangsaan. SMA Taruna Nusantara beralamatkan di Jalan Raya Purworejo Km 5 Banyurojo, Mertoyudan, Magelang, Jawa Tengah. 56172.

Ada beberapa penelitian terdahulu yang menggali pembudayaan nilai-nilai Pancasila, di antaranya penelitian Adi (2016) yang berjudul Pembudayaan nilainilai Pancasila bagi masyarakat sebagai modal dasar pertahanan nasional Negara Kesatuan Republik Indonesia. Penelitian ini menggunakan pendekatan deskriptif kualitatif dengan studi kasus dari media massa baik cetak maupun elektronik. Hasil penelitian menunjukkan bahwa pemikiran untuk pelaksanaan pembudayaan nilai-nilai dasar negara, seyogyanya dikembangkan secara melembaga, konsepsional dan fungsional oleh negara dengan mendaya gunakan semua kelembagaan dan komponen bangsa. Perbedaan dengan penelitian ini dari pendekatan, jenis dan subjek penelitiannya. Penelitian Amir (2013) yang berjudul Pancasila as integration philosophy of education and national character. Penelitian ini menggunakan analisis deskriptif. Hasil yang diperoleh dalam penelitian ini bahwa refleksi nilai-nilai Pancasila dalam pendidikan akan mengembalikan pudarnya identitas nasional Indonesia. Persamaan dengan penelitian ini bagaimana cara pembudayaan nilai-nilai Pancasila. Perbedaan dengan penelitian ini pendekatan penelitian dan subjek penelitian.

Berdasarkan uraian hasil penelitian yang relevan di atas dapat dikatakan bahwa sekolah memiliki peran yang strategis dalam pembentukan ketahanan pribadi berbasis nilainilai Pancasila terutama bagi generasi muda. Dengan demikian diperlukan strategi-strategi yang efektif untuk membentuk ketahanan pribadi berbasis nilai-nilai Pancasila agar terwujud kesadaran bernegara pada generasi muda. Untuk itu, tulisan ini akan dibagi dalam beberapa bagian. Pertama, tulisan ini akan menguraikan mengenai keterkaitan nilai-nilai Pancasila, ketahanan pribadi, dan pendidikan. Kedua, tulisan ini akan memaparkan analisis dari hasil penelitian tentang strategi pembentukan ketahanan pribadi berbasis nilainilai Pancasila untuk mewujudkan kesadaran bernegara di SMA Taruna Nusantara. Ketiga, tulisan ini akan menguraikan pentingnya pembentukan ketahanan pribadi berbasis nilainilai Pancasila untuk mewujudkan kesadaran bernegara di SMA Taruna Nusantara. Pada akhir tulisan akan dipaparkan kesimpulan yang menjelaskan kontruksi teori dari hasil temuan dalam penelitian. 
Penelitian ini disusun dengan pendekatan kualitatif dengan jenis studi kasus karena akan mempelajari proses sosial atau perilaku manusia (Stenius, Mäkelä, Miovský, and Gabrhelík, Roman. 2017: 156). Penentuan subjek menggunakan teknik purposive. Pengumpulan data dengan menggunakan observasi dan wawancara tatap muka secara langsung dan dalam kondisi yang alami/ natural " (Nugrahani, 2014: 19). Komponen analisis data menggunakan interactive models (Miles, Huberman, and Saldaña, 2014: 33) dan keabsahan data penelitian ini menggunakan member check yaitu prosedur pengecekan kembali data hasil penelitian dengan informasi dari informan yang ditunjuk dalam penelitian ini (Cresswell, 2013: 191).

\section{PEMBAHASAN}

\section{Keterkaitan Nilai-Nilai Pancasila,} Ketahanan Pribadi, dan Pendidikan

Pancasila sebagai dasar dan pandangan hidup mengandung nilai-nilai luhur yang wajib dijadikan pedoman oleh seluruh komponen bangsa Indonesia, bahkan sudah seharusnya menjadi karakter hidup masyarakat Indonesia. Menurut Veugelers (2019: 3) yang dimaksud karakter adalah konsep diri seseorang yang lebih mengacu pada perilaku dan mengekspresikan secara eksplisit gagasan yang tertanam di dalamnya. Selain itu, Subianto (2013: 335) menyebut karakter sebagai perilaku manusia yang terkait nilainilai yang berasal dari Tuhan Yang Maha Esa, sesama manusia dan lingkungan. Dari dua pendapat di atas, dapat disimpulkan karakter merupakan sifat pribadi seseorang yang relatif mapan/tidak berubah-ubah dan memiliki kekuatan/ketahanan pribadi yang kuat.

Warga negara Indonesia yang memiliki ketahanan pribadi yang kuat akan menunjukkan pola perilaku warga negara yang memancarkan jiwa ke lima sila Pancasila. Karakter baik akan memperkokoh kejayaan dan persatuan bangsa ini sehingga tidak mudah terpecah belah bahkan terkikis oleh perubahan zaman. Untuk dapat mengamalkan nilai-nilai yang terkandung dalam Pancasila, maka tiap warga negara harus terlebih dahulu memahami maksud dan tujuan dari para pendiri bangsa Indonesia dalam merumuskan Pancasila. Salah satu bacaan yang dapat dijadikan sumber historis Pancasila adalah buku tulisan Hidayat (2017).

Hidayat (2017) dalam buku berjudul Pancasila: pendiri RI dan problematiknya, menegaskan pernyataan Soekarno sebagai konseptor Pancasila bahwa manusia yang mendiami wilayah di Indonesia memiliki jiwa, watak atau karakter yang religius. Manusia Indonesia senantiasa beragama dan senantiasa ber-Tuhan, menyatakan bahwa Tuhan itu benar-benar ada, maka dari itu dimasukannya konsep ketuhanan dalam Pancasila. Manusia Indonesia juga memiliki jiwa sama rasa "adil" dan sama kesejahteraannya, tidak ada perbedaannya antarmanusia yang berbeda kewarganegaraan sehingga sangat penting apabila ada kerja sama antara manusiamanusia di dunia.

Pada rumusan sila ke tiga Soekarno menyatakan keberadaan bangsa Indonesia karena adanya kehendak untuk bersatu, persatuannya timbul karena persamaan nasibnya, persatuan antara tanah air dan penduduknya. Oleh karena itu, apabila persatuan ini lahir atas kesadaran seluruh rakyat Indonesia maka Indonesia akan menjadi bangsa yang kuat dan tidak mudah hancur. Dasar dari lahirnya sila ke empat karena persatuan yang lahir akibat dari mufakat yang terjadi. Kata mufakat inilah 
yang meletakkan dasar negara demokrasi (demokrasi kerakyatan). Pernyataan Soekarno yang terakhir bahwa ide dari ekonomi kerakyatan atau sosialisme ala Indonesia untuk mewujudkan masyarakat adil dan makmur berkeadilan sosial. Dari penjabaran Hidayat di atas menunjukkan betapa pentingnya ruh Pancasila sebagai petunjuk hidup agar tetap berdiri kokoh Negara Kesatuan Republik Indonesia tercinta ini.

Pancasila sebagai petunjuk hidup warga negara Indonesia perlu dirawat dan dijaga agar nilai-nilai yang terkandung di dalamnya dapat diamalkan sesuai dengan makna yang dikandungnya dan tidak ada siapapun yang berani membelokkan dari makna yang sebenarnya. Tidak ada kamusnya Pancasila digantikan oleh ideologi lain (Ryacudu, 2019).

Strategi penjagaan terhadap nilai-nilai Pancasila harus lebih dekat dan responsif sesuai persoalan publik dan tantangan perkembangan zaman (Latif, 2018). Nilai-nilai Pancasila harus diperkenalkan kepada tiap generasi sebagai pedoman berperilaku. Pembentukan watak karakter Pancasila dapat dimulai dari lingkungan terkecil yaitu keluarga. Keluarga sebagai lingkungan pertama dan paling utama dalam memperkenalkan nilai-nilai kebaikan dan keluhuran Pancasila. Selain keluarga, sekolah dan lingkungan masyarakat juga mempunyai peran penting dalam penanaman dan pembudayaan nilai-nilai luhur Pancasila. Ketiga lingkungan tersebut harus bersinergi. "Antara satuan pendidikan, keluarga dan masyarakat harus berkemauan untuk memberdayakan dan membudayakan nilai moral Pancasila yang dilandasi dengan keteladanan" (Puskur Balitbang, 2019: 3). Dengan kebijakan pemerintah Indonesia yang mewajibkan adanya pendidikan dasar 12 tahun, maka sekolah mempunyai andil besar dalam membentuk ketahanan pribadi siswa, sekolah dapat dijadikan tempat pengembangan karakter yang baik (Martoredjo, 2016: 120).

Sekolah merupakan tempat mendidik individu menjadi manusia secara utuh (Siswoyo, 2013: 136). Menurut UndangUndang No 20 Tahun 2003 tentang Sistem Pendidikan Nasional, yang dimaksud pendidikan nasional adalah pendidikan yang berdasarkan Pancasila dan UUD NRI Tahun 1945 yang berakar pada nilai-nilai agama, kebudayaan nasional Indonesia dan tanggap terhadap tuntutan perubahan zaman. Hal tersebut menunjukkan bahwa pendidikan di Indonesia bertujuan untuk membentuk manusia Indonesia secara utuh sesuai dengan Pancasila dan UUD NRI Tahun 1945. Secara sederhana dapat dikatakan bahwa antara pendidikan dan Pancasila memiliki hubungan yang kuat dan tidak dapat dipisahkan.

Pendidikan itu sendiri menghendaki dalam proses pembelajarannya mengembangkan olah pikir, olah rasa, olah karya dan olah tindakan (Tjiptabudy, 2010: 3). Oleh karena itu, pendidikan tidak hanya dilakukan untuk memberikan mengembangkan aspek kompetensi kognitif semata. Pendidikan memiliki peran yang kompleks dalam mengembangkan kompetensi yang ada dalam diri siswa. Adapun kompetensi yang harus dimiliki siswa antara lain kekuatan spiritual keagamaan, pengendalian diri, kepribadian, kecerdasan, akhlak mulia, serta keterampilan yang diperlukan sebagai bagian dari masyarakat, bangsa dan negara (Elsam, 2014).

Sekolah sebagai satuan pendidikan menjadi salah unsur penting dalam membentuk manusia Indonesia yang tangguh dan unggul. Apabila nilai Pancasila itu benar-benar dihayati dan dijadikan pedoman berperilaku 
generasi muda, maka Pancasila dapat menjadi perekat dan mengarahkan kekuatan bangsa dalam membentuk ketahanan pribadi generasi muda yang tangguh dan unggul. Indikator kepribadian yang tangguh dan unggul yaitu semakin tinggi nilai keimanannya, dapat bekerja sama dalam perbedaan, menghormati dan menghargai antarsesama, bersatu menjadi bangsa yang hebat, bermufakat dalam menyatukan pendapat dan mengambil kebijakan demi kepentingan bangsa serta menjunjung tinggi rasa keadilan demi tegaknya hukum positif.

Latif (2018) menambahkan bahwa pendidikan harus menjadi landasan utama dalam membentuk karakter pribadi seseorang. Pendidikan tidak sekedar memberikan transfer pengetahuan dan keterampilan tetapi harus mempersiapkan siswa menjadi calon warga negara yang baik. Calon warga negara untuk dapat menjadi warga negara yang baik membutuhkan pelatihan dan instruksi umum dalam tugas dan perannya sebagai calon warga negara (Edward. 2018: 15). Perlu adanya peningkatan rasa kepedulian sosial untuk mempertahankan kelangsungan hidup bangsanya (Budiwibowo, 2016).

Tata nilai Pancasila harus menjadi prioritas utama yang harus dijaga dan dipertahankan, dengan demikian pembentukan karakter di tingkat dasar akan lebih mengena sasaran dan lebih sistematik pelaksanaannya, dapat secara bertahap diperkenalkan sesuai dengan kebutuhan usia seseorang. Pendidikan karakter diupayakan melalui proses pembimbingan siswa hingga sampai adanya perubahan perilaku, sikap, budaya hingga terwujud komunitas yang beradab (Aushop, 2014: 7).

Ada delapan belas nilai karakter rumusan dari Kementerian Pendidikan Nasional yang menjadi pedoman bagi pendidik dalam penanaman dan pembudayaan nilai-nilai Pancasila untuk membangun dan menguatkan karakter bangsa sebagai ketahanan pribadi. Nilai-nilai tersebut antara lain nilai religius, jujur, toleransi, disiplin, kerja keras, kreatif, mandiri, demokratis, rasa ingin tahu, semangat kebangsaan, cinta tanah air, menghargai prestasi, bersahabat/ komunikatif, cinta damai, membaca, peduli lingkungan, peduli sosil dan tanggung jawa (Kemdiknas, 2010). Delapan belas nilai karakter ini diambil dari nilai budaya luhur masyarakat asli Indonesia. Usaha pembudayaan dapat dilakukan dengan melibatkan multipendekatan, multidisiplin, dan multimedia bagi generasi saat ini (Latif, 2018). Sebagai perwujudan pembentukan ketahanan pribadi berbasis nilai-nilai Pancasila dapat melalui beberapa hal yaitu penerapan budaya sekolah, kegiatan terproyek dan pola pembelajaran guru di kelas.

\section{Strategi Pembentukan Ketahanan Pribadi Siswa Berbasis Nilai-Nilai Pancasila Untuk Mewujudkan Kesadaran Bernegara di SMA Taruna Nusantara}

Terdapat tiga strategi yang diterapkan oleh SMA Taruna Nusantara untuk membentuk ketahanan pribadi siswa berbasis nilai-nilai Pancasila yaitu:

\section{Pembentukan Ketahanan Pribadi Berbasis Nilai-Nilai Pancasila Melalui Budaya Sekolah}

Pembentukan ketahanan pribadi berbasis nilai-nilai Pancasila dapat dilakukan dengan penciptaan budaya sekolah yang sesuai dengan karakter nilai-nilai sila Pancasila. Penciptaan budaya sekolah harus di pahami dan di dukung seluruh unsur pemangku kepentingan pendidikan seperti kepala sekolah, guru, dan 
tenaga kependidikan (Puskur Balitbang, 2019: 2). Sekolah dapat mendesain pendidikan karakter melalui kurikulum yang berlaku dan pranata sosial sekolah sesuai karakteristik lingkungan. Tidak cukup menyampaikan pesan-pesan moral saja tetapi juga harus pembuatan peraturan yang konsisten dan tegas (Koesoema, 2010). Bukti aktualisasi nilainilai Pancasila sesuai dengan sila Pancasila di SMA Taruna Nusantara melalui budaya sekolah terlihat dari, pertama, pengamalan sila pertama sekolah memberikan fasilitas sarana dan prasarana berupa ruang keagamaan yang dapat digunakan sebagai tempat aktivitas koordinasi kegiatan keagamaan, tempat ibadah, dan sebagainya. Ruangan diadakan sesuai jumlah agama yang dianut oleh siswa yaitu 5 agama. Pemberian fasilitas tidak membedakan antara pemeluk agama minoritas dan mayoritas. Selain itu, bisa juga pemberian fasilitas dalam peringatan hari besar keagamaan yang diadakan di sekolah unsur kepanitiannya mengikutsertakan peran guru dan siswa yang berlainan agama, contohnya saat kegiatan pemotongan hewan qurban Idul Adha kepanitiaan didukung oleh guru dan siswa yang beragama non Islam. Bahkan menurut sumber Radarsemarang.id $(11 / 8 / 2019)$ siswa non Islam juga diijinkan untuk menyumbang hewan qurban. Selain itu, aktualisasi sila pertama dalam bentuk pengucapan salam 5 (lima) agama di berbagai kegiatan yang diselenggarakan sekolah, yaitu Assalamualaikum warahmatullahi wabarakatuh, Salam sejahtera. Shalom. Om Swastiastu. Namo Buddhaya

Kedua, aktualisasi sila kedua kemanusiaan dengan terdapatnya program seperti pemberian kesempatan/peluang maju dan berprestasi bagi seluruh siswa tanpa ada diskriminasi, pemberian beasiswa bagi anak dari keluarga kurang mampu, pemberian penghargaan bagi siswa berprestasi peraih kejuaraan atau lomba baik tingkat lokal intern sekolah, tingkat daerah, tingkat nasional dan tingkat internasional, berempati pada keluarga guru atau keluarga siswa yang sedang mengalami bencana, dan masih banyak lagi program budaya sekolah sesuai sila ke dua Pancasila.

Ketiga, pengamalan sila ke tiga persatuan diajarkan kepada siswa untuk mewujudkan persatuan bangsa dengan berbagai kegiatan sekolah seperti pameran budaya "Pandatara/ Pameran Seni Budaya Nusantara" dan ajang bakat atau prestasi yang dimiliki siswa dari asal tinggalnya, lomba antarangkatan seperti futsal, basket, halang rintang atau lombalomba lain sebagai kompetisi yang menantang dan membutuhkan kekompakan, solidaritas bersama, penumbuhan rasa nasionalisme, pantang menyerah (jiwa patriotisme).

Keempat, pengamalan sila ke empat kerakyatan dilaksanakan dengan contoh belajar demokrasi yang dituangkan dalam kegiatan praktik pelaksanaan pemilihan pengurus OSIS (Organisasi Siswa Intra Sekolah) dan MPK (Majelis Perwakilan Kelas) diawali dengan unjuk bakat, penilaian prestasi, dan dilakukan dengan cara votting. Selain itu, terdapat bentuk-bentuk kegiatan kesiswaan yang dilakukan secara berkelompok yang mendukung adanya musyawarah mufakat seperti kelompok peleton, kelompok tim maple, dan sebagainya.

Kelima, aktualisasi sila kelima keadilan sosial dengan menjaga harmonisasi dan keseimbangan hidup dengan pemberian peluang yang sama untuk seluruh warga sekolah berpartisipasi dalam setiap kegiatan sekolah tanpa adanya diskriminasi sebagai contohnya jumlah siswa dibagi rata masuk 
dalam kegiatan ekstrakurikuler sekolah sehingga semua siswa merasa mempunyai peran dan tidak hanya sebagai pelengkap kuota sekolah saja, semua siswa wajib mengembangkan diri melalui kegiatan ekstrakurikuler ini.

Budaya sekolah juga tampak dalam kebiasaan-kebiasaan yang diberlakukan secara umum di lingkungan sekolah seperti budaya kejujuran, budaya antre, budaya pemberian reward bagi guru dan siswa berjasa bagi kemajuan sekolah, pemberian punishment bagi warga sekolah yang melanggar aturan diberikan tanpa adanya tebang pilih. Budaya sekolah dari sisi keteladanan ditunjukkan oleh kepala sekolah, guru dan tenaga kependidikan. Kepala sekolah, guru dan tenaga kependidikan memberikan keteladanan dalam bersikap, bertutur kata serta berpakaian yang rapi dan sopan, dengan demikian dapat menjadi contoh bagi siswa. Para pemangku kepentingan pendidikan terlihat menjunjung tinggi kesusilaan dan kesopanan sehingga siswapun terlihat sungkan atau berpikir ulang ketika akan melakukan perbuatan yang melanggar aturan sekolah. Demikian juga ditemukan pemasangan slogan-slogan ajakan bagi semua warga sekolah melakukan kebiasaan yang baik. Slogan-slogan yang selalu mengingatkan dalam segala kebaikan ditempel pada dinding sekolah yang bisa di baca secara umum seperti slogan ajakan "Sapa, Senyum, Salam", penempelan prasasti kode etik sekolah, pemasangan plakat hindari bullying, bersatu kita teguh bercerai kita runtuh, harap tenang ada ujian/harap tenang di Ruang Baca Perpustakaan (RBP), dan katakata Mutiara dari Bung Hatta yang berbunyi "Kurang cerdas dapat diperbaiki dengan belajar, kurang cakap dapat dihilangkan dengan pengalaman, namun tidak jujur itu sulit untuk diperbaiki”. Budaya sekolah yang sudah diterapkan di SMA Taruna Nusantara ini memberikan contoh keteladanan yang harus dilaksanakan demi pengembalian nilainilai Pancasila yang mengalami kemerosotan dalam pengamalannya. Hal ini didukung hasil penelitian dari Wahana (2015: 19) bahwa "semakin tinggi budaya sekolah maka semakin tinggi pula ketahanan pribadi". Dengan demikian, peran sekolah sangat efektif dalam pembentukan ketahanan pribadi bersasis nilainilai Pancasila untuk membangun kesadaran bernegara.

\section{Pembentukan Ketahanan Pribadi Berbasis Nilai-Nilai Pancasila Melalui Kegiatan Terproyek}

Pembentukan ketahanan pribadi berbasis nilai-nilai Pancasila di SMA Taruna Nusantara terdapat pada kegiatan terproyek yang sudah disusun berdasarkan mata kegiatan tiap tahun pelajaran berjalan seperti kegiatan lombalomba peringatan hari Kartini setiap bulan April dengan lomba membuat novel cerita kepahlawan pejuang wanita di Indonesia masa lalu dan masa kini, peringatan bulan Bahasa setiap bulan Oktober dengan lomba membuat puisi karya siswa dari perwakilan tiap kelas yang menceritakan kebesaran tanah air Indonesia. Peringatan hari ulang tahun kemerdekaan RI pada bulan Agustus dengan lomba sosio drama perjuangan kemerdekaan yang dilombakan antarkelas, kegiatan lomba baris berbaris antarkelas. Peringatan hari Pahlawan setiap bulan November dengan contoh lomba membuat vlog atau film pendek kepahlawanan yang diperankan oleh siswa. Pelaksanaan kegiatan terproyek harus selalu mengalami inovasi sehingga berdaya tarik bagi siswa untuk ambil bagian kepanitian dan menjadi peserta lomba, tidak hanya 
sekedar penonton. Para pemenang lomba akan di tampilkan setiap ada event sekolah dan bisa sebagai ajang pencarian bakat untuk diikutsertakan lomba secara eksternal. Hal ini bisa dijadikan sebagai modal promosi bagi sekolah dalam rangka rekruitmen siswa baru.

Kegiatan terproyek untuk menggali nilai-nilai Pancasila tidak sekedar yang disebutkan di atas, tetapi terdapat juga dalam program kegiatan Napak Tilas Perjuangan Jenderal Sudirman (RPS) untuk siswa kelas $\mathrm{X}$, program kegiatan Hulu Balang untuk kelas XI, dan Latihan Kemasyarakat Peduli Lingkungan (LKPL) untuk kelas XII. Kegiatan ini terbukti melatih dan mendekatkan para siswa dengan lingkungan masyarakat yang sebenarnya. Memberikan pemahaman bahwa masyarakat Indonesia bersifat multikultur dan bahwa bangsa Indonesia adalah bangsa yang majemuk, memiliki keberagaman dengan semboyan Bhinneka Tunggal Ika harus mampu membangun kebersamaan dalam perbedaaan yang nyata. Agar para siswa terbiasa dengan lingkungan sekitar, maka para siswa harus memiliki sikap membumi tidak pilih-pilih. Pengajaran ini tidak bisa hanya memberikan pesan-pesan materi di kelas melainkan harus berpraktik secara nyata di kehidupan masyarakat yang disebut juga “pembelajaran outdoor"(Wibowo, 2010: 2). Pembelajaran secara out door dapat menarik minat para siswa untuk mengikutinya dan tentunya akan membuka peluang partisipasi aktif siswa dalam mengenal lingkungan. Para siswa diberikan pelatihan dan pembimbingan secara bertahap dengan belajar berpikir kritis, berani bersikap mengambil keputusan untuk kemaslahatan bersama. Dengan harapan tumbuhnya kemandirian dan kesadaran secara kolektif.

\section{Pembentukan Ketahanan Pribadi Berbasis Nilai-Nilai Pancasila Melalui Pembelajaran Guru di Kelas}

Menurut Koesoema (2010) membentuk ketahanan pribadi berarti memperkuat karakter. Jika ingin pendidikan karakter secara utuh dan efektif tersampaikan pada siswa maka tergantung pada desain kelas. Desain kelas memberikan hasil yang efektif ketika terdapat upaya membangun relasi yang baik antara guru dengan siswanya sehingga suasana belajar menjadi nyaman. Seorang guru harus memiliki empat kompetensi dasar yaitu kompetensi pedagogis, kompetensi personal, kompetensi profesional dan kompetensi sosial (Normansyah, 2018: 7). Untuk membangun desain kelas dengan hasil efektif, guru harus mampu menyeimbangkan perkembangan kompetensi dasar. Seorang guru menunjukkan sebagai guru yang berkualitas jika guru tersebut mampu mengelola administrasi, mengelola kelas, mampu membimbing, mengarahkan dan menjadi contoh bagi anak didiknya. Seperti contoh dalam penyampaian materi harus dikaitkan dengan kehidupan sehari-hari dan mengikuti perkembangan yang ada. Demikian juga, pembelajarannya akan disukai dan lebih mudah dipedomani oleh para siswa jika pembelajaran dilakukan oleh guru yang inovatif, guru yang mampu memvariasi media pembelajaran. Pembelajaran di era milenial tidak dapat sekedar mengandalkan cara-cara konvensional melainkan juga harus mengikuti perkembangan anak di era milenial bahwa mereka lebih cepat menangkap capaian kompetensi dasar (KD) menggunakan media audio atau audio visual. Beberapa cara pembelajaran nilai-nilai Pancasila di era milenial yang dinilai mampu menarik perhatian para siswa menurut Wisudo et. al. (2012) dapat dicontohkan dengan cara guru 
membuat vlog dalam presentasi mengajar. Guru menyampaikan tantangan kompetensi dasar yang harus dicapai siswa seperti nilai pantang menyerah, kejujuran, kekompakkan, tanggungjawab.

Setelah peneliti melakukan observasi kelas pada guru mata pelajaran PPKn dan guru mata pelajaran bahasa Indonesia, terdapat proses pembelajaran di kelas yang mempergunakan variasi media pembelajaran. Hal ini dibuktikan bahwa guru mata pelajaran bahasa Indonesia membuat vlog untuk sinopsis perjuangan para pahlawan, sinopsis atlet nasional dan sebagainya. Tantangan guru ini sangat diapresiasi siswa. Selain itu, guru mengajar dengan menggunakan puisi untuk penyampaian pesan belajar seperti puisi berjudul "Jembatan" karya Sutardji Cholzoum Bachri. Puisi yang menggali nilai-nilai keadilan sosial, kemanusiaan, solidaritas dan nasionalisme. Puisi dengan judul "Sajak orang kepanasan" karya WS Rendra, "Negeriku" karya A Mustofo Bisri, "Di bawah kedamaian palsu" karya Widji Thukul, "Panorama tanah air" karya Ajip Rosidi. Puisi-puisi ini menggali nilai-nilai kemanusiaan, keadilan dan demokrasi.

Guru juga menggunakan cerpen atau cerita pendek dalam menyampaikan nilai-nilai Pancasila sebagai contoh cerpen "Anjinganjing penjaga kuburan" karya Kuntowijoyo, "Robohnya surau kami" karya AA Navis, "Tujuh belas tahun lebih empat bulan" karya Ratna Indraswari Ibrahim. Cerpencerpen tersebut menggali nilai ketuhanan, kemanusiaan dan keadilan sosial. Selain itu, terdapat variasi media pembelajaran dengan menggunakan film pendek, video klip, lagu, berita televisi majalah/koran, foto/gambar, novel. Contoh pemutaran film pendek berjudul "Jermal tahun 2005" yang menggali nilai ketuhanan, kemanusiaan, keadilan sosial, toleransi dan pantang menyerah. Demikian juga melalui pemberian novel pada kompetensi dasar yang tepat seperti novel "Banten Selatan" karya Pramoedya Ananta Toer dan novel "Pangeran yang selalu bahagia" karya Oscar Wilde (dari Yayasan Obor,2001) yang menggali nilai kemanusiaan, keadilan sosial, keberanian dan pantang menyerah

Pada mata pelajaran PPKn guru melakukan pemutaran video klip "Dilarang makan krupuk" produksi dari Insist yang mengajarkan nilai ekonomi kerakyatan, kemanusiaan, nasionalisme, dan budaya instan. Pemutaran lagu "Tell me why" yang dinyanyikan oleh Declan Galbraith menggali nilai keadilan sosial, solidaritas, kemanusiaan, dan kepedulian terhadap orang lain. Penggunaan berita televisi/ majalah/koran sebagai cara mengungkapkan nilai Pancasila tentang kemanusiaan dan keadilan sosial seperti kasus hukum nenek Minah, kasus pembunuhan Salim Kancil, Kasus kematian wartawan Safrudin yang menggali nilai-nilai kemanusiaan, keadilan sosial dan solidaritas, penyajian foto/gambar anak kecil di Afrika yang kurus tinggal tulang belulang dan sekarat mau mati karya Kevin Charter menggali nilai ketuhanan, kemanusiaan, keadilan sosial dan nilai baik-buruk, dan tentunya masih banyak lagi media yang dapat digunakan guru untuk membuat daya tarik kegiatan penyampaian nilai-nilai Pancasila dalam pembelajaran seperti menghubungan materi dengan isu-isu aktual ketahanan nasional (dalam bidang ipoleksosbudhankam) sehingga proses pembelajaran menjadi wadah membentuk ketahanan pribadi yaitu pribadi yang ulet, tanggung dan percaya diri (Haryati, 2018).

Selain guru menggunakan media yang bervariasi, guru juga telah mempersiapkan 
penilaian dengan baik agar tidak menimbulkan salah penilaian atau dianggap pilih kasih. Guru telah mempersiapkan indikator penilaian sesuai dengan ketentuan KD (kompetensi dasar materi). Penilaian yang cocok dalam pembelajaran ini dengan menggunakan penilaian autentik. Menurut Sani (2016) penilaian autentik adalah penilaian rangkaian pembelajaran dengan penilaian praktik, terproyek, dan portofolio dengan pemberian nilai yang berdasar keadilan dan menghargai hasil karya maka para siswapun akan semakin bersemangat dan menghasilkan karya yang inovatif ketika mengerjakan tugas yang diberikan oleh guru. Buah dari semangat dan karya yang inovatif akan membentuk pribadi yang percaya diri, berpikir kritis, berorientasi terhadap pemecahan suatu masalah dan menjadi salah satu bagian dasar pembentukan ketahanan pribadi.

\section{Pentingnya Pembentukan Kesadaran Pribadi Berbasis Nilai-Nilai Pancasila Untuk Membentuk Kesadaran Bernegara di SMA Taruna Nusantara}

Upaya pembentukan ketahanan pribadi berbasis nilai-nilai Pancasila untuk membangun kesadaran bernegara harus secara terus menerus dilakukan sehingga dapat mengatasi krisis jati diri bangsa dan demi tetap tegaknya Negara Kesatuan Republik Indonesia. Pembudayaan nilai-nilai Pancasila sudah menjadi tanggung jawab semua komponen negara, salah satunya melalui dunia pendidikan. Dengan pembudayaan nilai-nilai luhur Pancasila diharapkan lahir kesadaran bernegara dari para siswa. Jika unsur kesadaran bernegara telah tumbuh maka harapannya mampu menjaga dan membentengi trend masa kini yang tidak sesuai dengan pola hidup masyarakat Indonesia. Utamanya trend sosial budaya yang sering dikenal dengan istilah budaya populer atau "P-O-P" yang mempengaruhi pola pikir, pola sikap dan pola tindak masyarakat Indonesia. Oleh karena itu, keberadaan Pancasila sangat penting tiada duanya.

Pancasila menjadi landasan dan lem perekat bagi bangsa, jika kehidupan bernegara tanpa landasan berpijak maka akan runtuh terpecah belah. Pancasila memiliki kesaktian karena merupakan fitrah bagi bangsa ini (Mahfud, 2013). Pancasila menjadi benteng dan filter yang kuat mampu membawa selamat bangsa Indonesia dari krisis global. Oleh karena itu, Pancasila tidak bisa digantikan oleh ideologi lain karena nilai-nilainya digali dari keluhuran budaya bangsa. Karena sifatnya yang fitrah itu, maka Pancasila kedudukannya sebagai jiwa bangsa. Dengan mendasarkan sebagai jiwa bangsa esensi Pancasila sebagai nilai harus dipedomani dalam praktik kehidupan yang nyata. Apabila suatu bangsa terjadi krisis budi pekerti/krisis jati diri maka penyebabnya adalah masyarakat yang tidak mampu lagi memedomani nilainilai luhur Pancasila. Menurut Hafsah (2013) pembudayaan nilai-nilai Pancasila harus terus menerus tiada henti-hentinya karena Pancasila sebagai ruang hidup yang dapat menjaga Indonesia tetap utuh sebagai bangsa dan mampu menjawab tantangan masa depan. Keyakinan bahwa Pancasila secara dinamis akan mampu merespon setiap perubahan di berbagai dimensi.

Nilai-nilai Pancasila sudah semestinya tercermin dalam kegiatan pendidikan. Para pemangku kepentingan pendidikan yaitu kepala sekolah, guru dan tenaga pendidikan mempunyai peran besar dalam memberi teladan dan pembentukan karakter siswa. Pembentukan karakter kepribadian sesuai 
dengan nilai-nilai yang diidealkan tidak bisa sekedar disampaikan dengan cara-cara konvensional melainkan harus dengan proses digitalisasi di era milenial ini. Cara-cara dengan audio dan audio-visual akan lebih cepat dipahami oleh generasi ini. Hal ini sesuai dengan pendapat Asshiddiqie (2011: 44-45) bahwa pendidikan nilai-nilai luhur Pancasila harus terlihat dalam proses belajar mengajar dan dapat dipraktekkan dalam kegiatan lapangan secara nyata. Pendidikan nilai-nilai Pancasila di SMA Taruna Nusantara sudah muncul pada kurikulum pendidikan dan dapat dicontohkan dari teladan perilaku kepala sekolah, para guru, dan semua pihak yang terkait dengan pendidikan siswa. Lebih lanjut menurut Asshiddiqie, dalam rangka pembudayaan nilai-nilai Pancasila dapat dikerjakan oleh semua pihak secara terkoordinasi pada kegiatan terproyek dan budaya sekolah.

Pancasila sebagai norma dasar mengandung prinsip spiritualitas, humanitas, nasionalitas, soverenitas dan soliditas bagi bangsa Indonesia. Penguatan Pancasila haruslah dilakukan dengan menghidupkan cara berpikir sintesis jika tidak akan menjadi seperti gelembung udara yang meriah namun mudah menguap di udara (Arif, 2019). Agar tidak menjadi gelembung udara maka pendekatannya dilakukan secara terus menerus dan menyatu dengan kehidupan sebenarnya. Khusus dalam dunia pendidikan dituntut untuk mampu membekali siswa dengan nilai-nilai ketuhanan, kemanusiaan, persatuan, kerakyatan dan keadilan sesuai dengan karakteristik yang melekat pada masyarakat Indonesia utamanya sesuai dengan karakteristik peserta didik. Dengan dibangunnya pemahaman anak sejak dini, arah dan desain pendidikan dapat secara langsung turut berperan dalam membangun tatanan sosial yang lebih baik. Sekolah sebagai agen perubahan sosial dan pusat kebudayaan mampu mengarahkan perubahan yang lebih baik. Untuk mensosialisasikan nilai-nilai Pancasila seorang guru harus kaya sumber belajar dan mampu menggunakannya secara beragam, guru harus mampu memahami gaya berpikir dan kultur hidup peserta didiknya sehingga mereka mampu mendesain konsep sosialisasi nilai-nilai tersebut. Adanya kesesuaian antara guru dengan peserta didik akan memunculkan ketertarikan pemahaman terhadap sesuatu yang sedang dipelajari dan memacu keinginan siswa untuk selalu berusaha dan mencapai sesuatu dengan kemampuan yang optimal/ terbaik.

Pentingnya pembentukan ketahanan pribadi dapat meminimalkan tindakan negatif karena pengaruh trend masa kini dan menjadikan kepribadian seseorang menjadi lebih bijak (Julkifli et al, 2020: 15). Terbukti sekolah telah menerapkan strategi yang cocok dengan kultur warga sekolah dan lingkungan sekolah. Dengan strategi yang tepat, pembudayaan nilai-nilai Pancasila telah menghasilkan nilai kepatuhan, tanggung jawab dan kesadaran bernegara pada diri para siswa.

\section{SIMPULAN}

Upaya pembentukan ketahanan pribadi berbasis nilai-nilai Pancasila untuk membangun kesadaran bernegara sudah semestinya dilakukan secara horizontal dengan melibatkan seluruh komponen negara seperti lingkungan keluarga, lingkungan pendidikan, lingkungan masyarakat, dan sebagainya sesuai dengan kapasitas dan posisinya masing-masing. Pembudayaan nilai-nilai Pancasila khususnya dalam dunia 
pendidikan membutuhkan strategi yang tepat dan sesuai dengan perkembangan siswa atau peserta didik.

Hasil dari penelitian ini menemukan beberapa strategi yang dapat digunakan sebagai upaya pembentukan ketahanan pribadi siswa berbasis nilai-nilai Pancasila khususnya di SMA Taruna Nusantara, yaitu penerapan budaya sekolah dengan menggunakan pendekatan keteladanan dan partisipatif dari semua warga sekolah, melakukan kegiatan terproyek, dan guru melakukan inovasi dalam proses pembelajaran. Pengalaman nilai-nilai Pancasila secara benar mampu menghasilkan ketahanan pribadi sebagai bekal membangun kesadaran kehidupan bernegara pada generasi muda khususnya siswa SMA Taruna Nusantara. Dengan pengamalan nilai-nilai Pancasila secara lahir dan batin membuahkan pribadi yang mampu mengendalikan ego dan mewujudkan kondisi kehidupan bersama yang nyaman, aman dan tenteram. Selain itu, pengamalan nilai-nilai Pancasila dapat mengembalikan jati diri bangsa Indonesia secara bertahap namun berhasil optimal dan tercapai kesadaran hidup bernegara.

\section{DAFTAR PUSTAKA}

Adi, P 2016, 'Pembudayaan nilai-nilai Pancasila bagi masyarakat sebagai modal dasar pertahanan nasional NKRI'. Unikama:. Jurnal moral kemasyarakatan. . vol 1, no. 1. Hh. 37-50.

Amir, S 2013, 'Pancasila as integration philosophy of education and national character'. International journal of scientific \& technology research, vol 2 , no. 1, hh. 54-57.

Arif, S 2019, 'Pancasila, Soekarno dan krisis sintesa bangsa'. Kompas.com, 31/5. https://nasional.kompas.com
Asmaroini, A,P 2017, 'Menjaga eksistensi Pancasila dan penerapanya bagi masyarakat di era globalisasi'. JPK: Jurnal Pancasila dan Kewarganegaraan, vol 1, no. 2, hh 50-64.

Asshiddiqie 2011, 'Membudayakan nilainilai Pancasila dan kaedah-kaedah Undang-Undang Dasar Negara Republik Indonesia Tahun 1945'. Jimly.com: Kongres Pancasila III, hh 33-47.

Aushop, A, Z 2014, 'Islamic character building: membangun insan kamil, cendekia berakhlak qurani'. Bandung: Grafindo Media Pratama.

Budiwibowo, S2016, 'Revitalisasi Pancasiladan bela negara dalam menghadapi tantangan global melalui pembelajaran berbasis Multikultural'. Citizenship Jurnal Pancasila dan Kewarganegaraan, vol 4, no. 2, hh 565-585.

Creswell, J, W 2013, 'Research design qualitative, quantitative, and mixed methods approaches'. 4 ed. SAGE Publications, Inc.

Edwards, S 2018, 'Youth movements, citizenship and the English countryside: creating good citizens'. Palgrave Macmillan. ISBN: 978-3-319-651569,978-3-319-65157-6

Elsam 2014, 'Referensi HAM'. https:// referensi.elsam.or.id

Hafsah 2013, 'Strategi pembudayaan nilainilai Pancasila di bidang pendidikan dan budaya dalam perspektif ke-indonesiaan'. Prosiding Kongres Pancasila V 2013, hh. 2.

Haryati, S 2018, 'Konstruksi isu aktual bidang ketahanan nasional untuk pengembangan isi pendidikan kewarganegaraan persekolahan'. Jurnal Ketahanan Nasional, vol. 24, no. 3, hh.342-353. 
Diyah Kartika Dewi, Sunarso -- Strategi Pembentukan Ketahanan Pribadi Siswa Berbasis Nilai-Nilai Pancasila Untuk Membangun Kesadaran Bernegara (Studi Di SMA Taruna Nusantara Magelang Jawa Tengah)

Hidayat, F 2017, 'Pancasila: perspektif pendiri RI dan problematikanya'. Bekasi: STBA Pertiwi (Personal archive).

Julkifli, J, Masrukhi, M, and Susilaningsih, E 2020, 'Learning strategy of Pancasila and citizenship education on students' character development'. Journal of Primary Education, vol. 9, no. 1. hh. 14-21.

Koesoema, D 2010, 'Pendidikan karakter integral'. Kompas.com, 11/2.

Latif, Y 2018, 'Wawasan Pancasila: bintang panuntun untuk pembudayaan'. Yogyakarta: Penerbit Mizan.

Mahfud 2013, 'Pancasila bawa Indonesia selamat dari krisis global'. Kompas.com, 27/2. https://nasional.kompas.com.

Martoredjo, N,T 2016, 'Building character through Pancasila values to sovereign nation'. Jurnal humaniora 7. vol. 7, no. 1, hh 116-121.

Milles, MB., Huberman, AM. And Saldaña, J 2014, 'Qualitative data analysis: A methods sourcebook'. Thirds editions. SAGE publications.

Normansyah, A,D 2018 'Educational management of children nations of culture Pancasila basic primary school in high class'. International conference: character building through pricesly international education. FKIP Unpas vol. 1 , no. 1. hh.72-75.

Nugrahani, F 2014, 'Metode penelitian kualitatif dalam penelitian bahasa'. Surakarta: Cakra.

Pusat Kurikulum dan Kebukuan Kemendiknas 2010, 'Panduan pendidikan karakter'. Jakarta: Kementerian Pendidikan Nasional

Pusat Kurikulum 2019, 'Penguatan pembelajaran nilai dan moral Pancasila', Jakarta: Balitbang.
Pratomo, Y 2013, 'Presiden SBY sedih masih banyak terjadi konflik horizontal'. Kompas.com, 11/12

Radarsemarang.id. 2019, 'Siswa non muslim ikut menyumbang hewan qurban'. 11/8. Ryacudu, R 2019, 'Tidak ada kamusnya Pancasila diganti ideologi lain'. Kompas.com, 12/8. https://nasional. kompas.com.

Sani, R,A 2016, 'Penilaian autentik'. Jakarta: Bumi aksara. ISBN 978-602-217-577-3.

Siswoyo, D 2013, 'Philosophy of education in Indonesia: Theory and thoughts of institutionalized state (PANCASILA)'. Asian Social Science, vol. 9, no. 12, hh 136.

Stenius, Kerstin., Mäkelä, Klaus., Miovský, Michal., \& Gabrhelík, Roman 2017, 'How to write publishable qualitative research'. Ubiquity press. Retrieved from https://www.jstor.org/stable/j. ctv3t5qxw.14

Subianto, J 2013, "Peran keluarga, sekolah dan masyarakat dalam pembentukan karakter berkualitas', Edukasi: Jurnal Penelitian Pendidikan Islam, vol. 8, no. 2.

Susatyo, B 2019, 'Pentingnya penanaman ideologi Pancasila bagi generasi muda' Kompas.com, 13/9. https://nasional. kompas.com .

Tjiptabudy, J 2010, 'Kebijakan pemerintah dalam upaya melestarikan nilai-nilai Pancasila di era reformasi'. Jurnal Sasi, vol. 16, no. 3 .

Undang-Undang Nomor 20 Tahun 2003 tentang sistem pendidikan nasional

Veugelers, W 2018, 'Moral and citizenship education in 21st century: The role of parents and the community'. In character education for 21 st century 
global citizens: proceedings of the 2 nd international conference on teacher education and professional development (INCOTEPD 2017), October 21-22, 2017, Yogyakarta, Indonesia, hh. 3.

Wahana, H, D 2015, 'Pengaruh nilai-nilai budaya generasi millennial dan budaya sekolah terhadap ketahanan individu (Studi Di SMA Negeri 39, Cijantung, Jakarta)'. Jurnal Ketahanan Nasional, vol. 21, no. 1, hh. 14-22. https://doi.org/10.22146/jkn.6890

Wibowo, Y 2010, 'Bentuk-bentuk pembelajaran outdoor'. Yogyakarta: FPMIPA UNY. http://staffnew.uny.ac.id/ upload/132302517/pengabdian/Bentukbentuk+ pembelajaran+outdoor.pdf
Widayanti, W.P., Armawi, A. and Andayani, B 2018, "Wawasan kebangsaan siswa sekolah menengah atas dan implikasinya terhadap ketahanan pribadi siswa (Studi pada siswa sekolah menengah atas (SMA) umum berasrama berwawasan nusantara, SMA umum di lingkungan militer dan SMA umum di luar lingkungan militer di kabupaten Magelang, provinsi Jawa Tengah)'. Jurnal Ketahanan Nasional, vol. 24, no. 1, hh.1-26.

Wisudo, B, Subkhan, E, Paat, L, F, Paat, J, P, Haryanto, Y, dan Jiwa, V, D 2012, 'Pancasila yang mencerdaskan. Sekolah tanpa batas'. Jakarta: Yayasan Tifa. www.sekolahtanpabatas.or.id. 